Vinnytsia Institute of Trade and Economics of Kyiv National University of Trade and Economics, Assistant Professor of the Department of Foreign Philology and Translation

\title{
PSYCHOLINGUISTIC PROFILE OF MODERN STUDENTS OF ECONOMIC SPECIALTIES
}

Within the article some aspects of manifestation of linguistic, terminological, communicative-pragmatic, textual, discursive competencies of the psycholinguistic profile of specialists in economic sphere are characterized. The influence of personal traits of an preceptor-economist on the formation of linguistic personality of an emerging economist is determined. Scientific works are analyzed, which allow to define a linguistic personality as a personality expressed in language and through language; as a person who is a native speaker and communicator, a holder of communicative competence. There are three levels of language proficiency: verbal-semantic, linguocognitive, pragmatic, the boundaries between which are quite fragile, vague; they also determine the stages of formation of linguistic personality. The requirements to the economic competence of a specialist are determined, which ensure the appropriate level of language proficiency, as lexical units of the language system occupy a priority place in professional speech of economic specialists: economic terminology of narrow and wide use, professionalisms, socially marked vocabulary, etc. The intralinguistic reasons for the dynamic penetration of lexical borrowings into professional speech of modern economists in connection with the nominative necessity are analyzed. With all due respect to foreign language culture, economic experts themselves are increasingly advocating the ecology of professional language, trying to use at least sporadically synonymous Ukrainian equivalents to the borrowings. Important communicative features of professional speech have been determined: content, accuracy, consistency, concise presentation of thoughts, provability, correctness and appropriateness of the terms use, information saturation, purity of speech, expressiveness of diction, melodiousness.

Thus, indicators of general cultural, linguistic, terminological competence of an economist are deep knowledge of features of economic terminology, theory and practice of speech influence, attentive attitude to specific vocabulary and professional terms. Formation of the psycholinguistic profile of the personality of a novice economist depends on the fundamental language training, example and influence of the personal traits of the preceptoreconomist. The language development of a modern students of economic specialties largely 
depends on the state support, but above all on their own desire for self-development and selfrealization.

Key words: language personality; language culture; economic branch; lexical borrowings; professional texts; terminological competence.

Problem statement. Dynamic situation on the present-day labor market, liberalization of national economic relations, globalization of the economy leads to the increased demands to the personal qualities of modern graduates of economic faculties. According to industry standards, an employee in the economic sphere must have sound professional knowledge, be responsive to changes in the financial, economic, banking, trade and economic sectors, be able to analyze, summarize and forecast the results of his own activities within a financial institution, bank, stock exchange. Employers' requirements have actualize, and surveys of bank employees have confirmed such professionally important qualities of economists as creative and analytical style of thinking, emotional stability and self-control, ability to generate new solutions to non-standard production situations and practical tasks, ability to establish business and partnership relations, awareness of spiritual values and standards of the profession.

Determinants in achieving professional success are, of course, the ability to correctly, reasonably build oral and written, verbal and nonverbal professional and business communication, to create specialized economic texts, the professional high level of which indicates maximum desire for continuous professional development, self-development and self-realization.

Thus, in conditions of economic model transformation in Ukraine, change of the country's economic development maintenance and style, integration of domestic economy into the world economic space there arises a need to carry out analysis of the advanced economic student psycholinguistic profile. Within the article we are going to characterize some aspects of manifestation of linguistic, terminological, communicative-pragmatic, textual, discursive competencies of the economic specialist's psycholinguistic profile, define the influence of personal traits of the preceptor-economist on the linguistic personality of the novice economist formation.

The purpose of the article is to analyze the psycholinguistic features of a modern student of economic specialties in the field of professional communication, which is formed in the appropriate environment and is largely determined by the worldview of the economist who strives for self-development and self-realization.

Presentation of the main research material. Theoretical basis of the study are the works that substantiate the specifics of the language personality (G. Bogin [3], Yu. Karaulov [1], N. Karpukhina, O. Selivanova [4], L. Struganets); the specifics of the text (N. Valgina [10 ], V. Chernyavska); of the discourse (F. Batsevych [5]); of the professional speech of economic specialists formation (V. Gordienko [7], I. Yaroshchuk [12]). The source base for examples of professional speech are the monographs and articles of the higher education lecturers, doctors of economics, professors.

The study of scientific works makes it possible to define a language personality as personality expressed in language (texts) and through language, reconstructed in its main features on the basis of linguistic means, a person who accumulates mental, social, cultural, ethical and other components reflected through its language and its discourse (Yu. Karaulov [1], L. Struganets [2]); as a native speaker who has the ability to speak (G. Bogin [3]); as personality who is a native speaker and communicator, a holder of communicative competence (Selivanova [4]).

Analysis of economic professional texts and professional economic speech convinces in accordance with the structure of the linguistic personality of the economist to the integral 
structure of the language personality, which was proposed by Yu. Karaulov [1, p. 79]. In particular, Russian scientist identifies three levels of language proficiency. Verbal-semantic level, or internal lexicon of the personality, is represented in the linguistic consciousness in the form of microsystems (lexical-semantic groups, grammar, phrases and sentences). The linguocognitive level is represented by the personality's thesaurus. Its units are concepts, symbol words, which each economist as a linguistic individual transforms in a more or less ordered and systematized linguistic picture of the world.

For the economist, the third, pragmatic level, or the level of activity-communicative needs, which is determined by cognitive activity, intellectual sphere, is conditioned by the specifics of economic discourse in a socio-pragmatic direction. The top of this level is creation of one's own idiosyncrasy (an economist prepares contracts, writes economic reports, scientific articles, etc.). In reality, the boundaries of these levels are quite fragile, vague, and the structural components - lexicon, thesaurus, pragmaticon - determine the stages of formation of a linguistic personality. Formation of a pragmatic psycholinguistic level of a personality, intelectual development, creativity, freedom of thought occurs over the course of life.

A broad economic outlook and economic competence play an important role in the development of the economist as a psycholinguistic personality, the foundation of which is knowledge not only of micro- and macroeconomics, stock exchange, organization and management of enterprises, auditing and accounting of financial documents, but also the history of Ukrainian and foreign literature, foreign and, of course, native, Ukrainian language. The basis of financial behavior is speech behavior, which must meet the norms of socioprofessional interaction [5, p. 228] and involves the ability to establish contact with interlocutors, to show professional approach to solving communicative tasks. To a large extent, these requirements are provided by an appropriate level of language competence.

As the analysis of economic scientific articles, lectures, videos of scientific forums shows, lexical units of the language system occupy a priority place in the professional speech of economic specialists: economic terminology of narrow and wide use, professionalisms, socially marked vocabulary, economic (stock exchange) jargon. Unfortunately, not Ukrainian specific words or phrases (попит, безстроковий вклад, господарський розрахунок, угода, управління, etc.) predominate among the frequently used ones, but numerous borrowings from English (banknote, leasing, business, broker, dealer, management), French (avance, accise, équilibre, prolongation), German (Buchhalter, Börse, Makler, Miete), Italian (banca, bancarotta, lordo, valuta, credito), Polish (bogactwo, konto, fundusze) and others. Sometimes economic texts are completely (up to $90 \%$ ) interspersed with borrowings.

Intensive introduction of lexical borrowings into the economic sphere of Ukraine is explained by external and internal factors. External factors include active economic contacts between Ukrainians and other peoples and the spread of the West Europian experience; emergence of new branches of economic activity (marketing, management); authority of the source language. Today, English has such preference. N. Popova on a sufficient number of examples shows the growth of the Anglicisms number in the thematic group "Economics, Banking and Finance" from 1930s till the beginning of the XXI century: in 1930s there were $4 \%$ of them; in 1970-80s - 7\%, in 1990s-2000 - 21.5\%, during 2000-2003 the number increased to $26 \%$ [6, p. 12]. Among the nominations of this group, 50\% have concepts related to economic, banking and financial activities (merchandising, styling, cross-rate, demarketing); $20 \%$ - names of items, business papers, contracts (futures, bonds, ecus); 16\% names of persons involved in economic, banking and financial activities (discount broker, brand manager, jobber, trader, dealer, distributor); $14 \%$ - names of institutions and premises in this area (factor company, business hall). 
Nominal necessity is considered to be the intralinguistic reason for the dynamic penetration of lexical borrowings into professional speech of the present-day economists. We point out, in particular, the lack of a corresponding word in the native language and the need to name a new subject, new phenomenon, concept (e.g., the word marketing has derived from the English word market, which means a wide range of activities in the goods, services, securities market); the need to distinguish words that have a similar meaning, but describe slightly different concepts (dealer-trader); saving language resources; tendency to replace phrases and descriptive expresions with one-word names (summit - a meeting at the highest level; voucher - privatization check).

With all due respect to foreign language culture, economic experts themselves are increasingly advocating for the ecology of professional speech. In their scientific works, using financial terminology, they try to at least sporadically apply synonymous Ukrainian equivalents. For example, quotation is the equivalent of встановлення курсу (setting the exchange rate); along with the word margin - the corresponding різниия иін (price difference). Borrowing preferences are replaced by the Ukrainin words пільги, переваги (benefits, advantages); hedging - on the equivalent зменшення ризику (risk reduction); futures - a corresponding угода на майбутнє (agreement for the future); dividend futures on the corresponding прибуток (profit); economical - on the equivalent ощзадивий of saving; discount - on the corresponding знижка (rebate). Of course, if a foreign word has additional semantic nuances, which are not present in the Ukrainian language, it is more appropriate to use a borrowed term.

Authors of economic texts try to distinguish between homonymous words when one and the same term "enters" different terminological systems. For example: the word onepauiя (operation) in medicine means surgery for medical purposes, in the military sphere fightings, united by a single purpose; in the technical one - a separate completed part of the technological process. Instead, in the financial sphere, the word операчія (operation) means a trade agreement, transaction. This token is the basis of such collocation as акредитивна операція (accreditation operation), безготівкова операція (non-cash operation), дисконтова операція (discount operation), спекулятивна операція (speculative operation), розрахункова операція (settlement operation), комериійна операція (commercial operation).

The highest level of language culture is observed when an economist tries to present a grammatically and stylistically appropriate expression in the Ukrainian language. Let's pay attention to the Russian terms and word combinations the translation of which caused difficulties for the teachers and students of the Vinnytsia Institute of Trade and Economics of the Kyiv National University of Trade and Economics: курировать - опікуватися (to supervise, to take care of); выпускаемая продукция - продукція, щуо випускається (manufactured products); привлекаемые инвестиции - залучені інвестиції (attracted investments); приобретаемые средства - споживчі кошти (purchased funds, consumer funds); безналичный расчет - безготівковий розрахунок (non-cash payment); действующее законодательство - чинне законодавство (current legislation). Such shortcomings can be avoided by constantly turning to dictionaries of professional (economic) orientation.

Abundance of professional speech of an economist is determined by his active vocabulary, and this, in turn, depends on the total stock of the language (words, meanings, patterns and phrases, typical intonations, connections and relationships in the text), the level of his speech competencies formation.

A special place in economic speech is occupied by jargon, which describes the movement of prices, the state of supply and demand on the stock exchange, etc. For example, a bull is a broker who plays for promotion; bear - a stock speculator who plays on the 
decline; dynamite - a dealer who sells unreliable securities; garbage - securities with a low level of liquidity; bucketing - an illegal attempt of a broker to collect additional amounts of commission by accelerated purchase and sale of securities on the instructions of clients [7, p. 215].

Slang vocabulary "promotes" the emergence of new names that are lexically and semantically related. For example: $a$ bear raid is an active "naked writing" sale, which is carried out in order to reduce prices to buy a good product; bear squeeze - measures officially taken by central banks in order to influence speculators on the currency exchange, who play to lower prices by short selling; bear market - a market in which there is a downward trend in prices.

Professional speech of an economist often sticks out due to the bright phraseology, which is based on the marked word. In the turn of speech of financial and economic professionals, for instance, the following stable phrases are often used: відкупити маржу (buy margin) - means the client's order to the broker to buy the nearest futures contract and sell the contract for a longer period); обідрана облігація (peeled bond) - means a bond with a separate interest coupon that can be withdrawn for redemption or for independent purchase and sale; копчений оселедецьь (smoked herring) - means the previous prospectus, which in general informs about the issuance of a bond loan [8, p. 123].

It is also useful to know the origin of individual phrases. In particular, the stable expression вуличнии ринок (street market - a network of intermediaries, buyers and sellers of securities that communicate with each other through telecommunications) emerged in the XVI-XVII centuries, when London brokers entered into transactions directly on the street or in a cafe. Now in such market bonds and shares of stock not included in the stock exchange list are sold. Some phraseological expressions are holistic terms, widely used in professional environment of economists. In particular, in the professional activities of brokers, dealers, an important role is played by the phrase біржова гра (stock exchange gamble). This is the name of speculative transactions on the stock exchange in order to make a profit by forecasting the dynamics of quotations of exchange goods, stock values, as well as due to the difference in quotations and exchange rates on different exchanges [9, p. 134].

The result of successful speech activity of an economist is a professional text (business papers, reports, scientific articles, monographs, speeches, expert opinions, speeches). With its typicality, each economic text is individual. It depends on the author, his erudition, experience of text creation, desire for self-expression (this is reflected in the author's methods of using different language tools). Scientific economic text should lead to a qualitative change (expansion, deepening) of the general world picture both of the author of the product and the consumer. For the creation of a scientific text, as N. Valgina convinces [10, p. 38], pragmatic setting of the text (determined by its type, genre, tasks) and pragmatic attitude of the author, which finds expression in the author's modality is important. Analysis of scientific texts shows that these pragmatic attitudes may conform, but may contradict each other. Thus, there arises a need for self-development of textual, genre competence of the psycholinguistic profile of the economist.

Financial institutions achieve high efficiency, when their employees carry out effective communicative interaction with colleagues, partners or customers and are able to substantiate options for solving economic problems, resolve complex professional situations, to work out business development strategies. To a large extent it depends on the acquired discursive competence (the word discursive (from Latin discursus - reasoning, argument, cause) is explained as one that is carried out by logical reasoning, prudent, indirect [11, p. 235]), which reflects the ability of linguistic individuals build and perceive discourses of different types (oral and written) in accordance with the communicative intention within a certain professional communication situation, taking into account the specifics of their semantic- 
pragmatic and grammatical organization at the macro- and micro-level and the relationship of extralinguistic and linguistic components [12, p. 27]. F. Batsevych characterizes the professional communicative situation as certain conditions of communication with the participation of communicators, which motivate them to interpersonal interaction. It "determines speech behavior, ways of realization of communicative intention (strategy, communication tactics, etc.)" [5, p. 229].

Important communicative features of professional speech are content, accuracy, logic, correctness, concise presentation of opinions, provability, correctness and appropriateness of the terms use, informative saturation, purity of speech, expressiveness of diction, melodiousness. Such oral speech culture was well mastered by Ukrainian economists M. Baludyanskyi, M. Bunhe, I. Franko, who actively worked in the field of classical economic theory of the XIX century.

In particular, I. Franko at the age of twenty-eight made a successful report on statistics as a method and as a science that is now considered to be classic. Every word of an experienced writer and economist radiated a powerful intellectual and emotional energy. The success of the writer and economist was evident. At the time when I. Franko lived in Galicia, people who had good command of the spoken word were greatly prized. O. Serbenska [13, p. 11] writes about various forms of public communication - meetings, talks, circles, gatherings, academies, where experts gave speeches, presented essays, lectures, reports, held debates. I. Franko considered the language personality as a linguistic individuality: "The most valuable and best thing in every man is his individuality, his spiritual face with all its separate features. The more such signs the person has, the more characteristic and harmonious, richer, stronger and nicer is his personality $<\ldots>[14$, p. 276].

Conclusions. Thus, the psycholinguistic personality of a modern student of economics is the so-called self-regulatory system that is subject to various social and economic changes and factors, language fashion in the field of economic communication, formed in a certain socio-cultural space, appropriate mental environment, is largely determined by the worldview. Professional speech from the point of view of the theory of psycholinguistic personality is a set of units of different levels of the language system (the article was mostly focused on the lexical level).

Indicators of general cultural, linguistic, terminological competence of an economist are deep knowledge of peculiarities of economic terminology, theory and practice of speech influence, attentive attitude to specific vocabulary and professional terms. This is facilitated by constant reading of foreign and domestic scientific economic literature, reference books, study of economic experience. Formation of the psycholinguistic profile of a student of economic specialties depends on the fundamental, language training, example and influence of the personality traits of the preceptor-economist and the teacher of philological disciplines. Linguistic development of the modern economist largely depends on state support, but above all on his own desire for self-development and self-realization.

\section{Jimepamypa}

1. Караулов Ю.Н. Русский язык и языковая личность. Москва: Наука, 2010. 363 с.

2. Струганець Л.В. Культура мови: словник термінів. Тернопіль, 2000. 88 с.

3. Богин Г.И. Типология понимания текста. Калинин, $1986.87 \mathrm{c.}$

4. Селіванова О.О. Сучасна лінгвістика: термінологічна енциклопедія. Полтава, 2006. C. 376.

5. Бацевич Ф.С. Нариси з лінгвістичної прагматики. Львів: ПАІС, 2010. 336 с.

6. Попова Н.O. Структурно-семантичні особливості новітніх лексичних запозичень 3 англійської в українську мову (90-і pp. XX ст. - початок XXI ст.). Запоріжжя, 2005. 19 с. 
7. Семеног O., Гордієнко В. Українська мова: професійне спрямування - біржова діяльність. Київ, 2007. С. 215-217.

8. Школьник I.O. Фінансовий ринок України: сучасний стан і стратегія розвитку. Суми, 2008. 348 с.

9. Крамаренко В.І., Холод Б.І., Воробйов Ю.Н. Біржова діяльність. Київ, 2003. 261 с.

10. Валгина Н.C. Теория текста. URL: http://www.evatist.ru/text14/01.htm .

11. Словник іншомовних слів / за ред. О.С. Мельничука. Київ, 1975. С. 215.

12.ЯрощукI. Діловий дискурс фахівця економічного профілю як комунікативне явище. URL: journal.mandrivets.com/images/file/Jaroshchuk_2012_3.pdf (12.04.2013).

13. Сербенська O. Мовлене слово у життєсвіті Івана Франка. URL: http://journ.lnu.edu.ua/publications/Zbirnyk07_Serbenska.htm

14. Франко I. Михайло Петрович Старицький : його ж, Зібрання творів в 50 т. $/$ Київ, 1986.

\section{References}

1. Karaulov Yu.N. (2010). Russkiy yazyk i yazykovaia lichnost [Russian language and linguistic personality]. Moskow, Nauka, 363 p..

2. Struhanets L.V. (2000). Kultura movy: slovnyk terminiv [Culture of language: a dictionary of

terms]. Ternopil, $88 \mathrm{p}$.

3. Bogin H.Y. (1986). Tipologiya ponimaniya teksta [Typology of text comprehension]. Kalinin, 87 p.

4. Selivanova O.O. (2006). Suchasna linhvistyka: terminolohichna entsyklopediia [Modern linguistics: terminological encyclopedia]. Poltava, $376 \mathrm{p}$.

5. Batsevych F.S. (2010). Narysy z linhvistychnoi prahmatyky [Essays on linguistic pragmatics]. Lviv, PAIS, 336 p..

6. Popova N.O. (2005). Strukturno-semantychni osoblyvosti novitnikh leksychnykh zapozychen z anhliiskoi v ukrainsku movu (90-i rr. XX st. - pochatok XXI st.) [Structural and semantic features of the latest lexical borrowings from English into Ukrainian (90s of the XX century - the beginning of the XXI century)]. Zaporizhzhia, 19 p..

7. Semenoh O. (2007). Ukrainska mova: profesiine spriamuvannia - birzhova diialnis [Ukrainian language: professional orientation - stock exchange activity]. Kyiv, pp. 215-217

8. Shkolnyk I.O. (2008). Finansovyi rynok Ukrainy: suchasnyi stan i stratehiia rozvytku [Financial market of Ukraine: current state and development strategy]. Sumy, $348 \mathrm{p}$.

9. Kramarenko V.I. (2003). Birzhova diialnist [Exchange activity]. Kyiv, 261 p.

10. Valgina N.S. Teoriya teksta [Text theory]. URL: http://www.evatist.ru/text14/01. htm (22.02.2013) [in Russian].

11. Melnychuk O.S. (1975). Slovnyk inshomovnykh sliv [Dictionary of foreign words]. Kyiv, p. 215..

12.Yaroshchuk I. Dilovyi dyskurs fakhivtsia ekonomichnoho profiliu yak komunikatyvne yavyshche. URL: http://journal.mandrivets.com/images/file/Jaroshchuk_2012_3.pdf （12.04.2013) [in Ukrainian]/

13. Serbenska O. Movlene slovo u zhyttiesviti Ivana Franka [A spoken word in the life of Ivan Franko]. URL: http://journ.Inu.edu.ua/publications/Zbirnyk07_Serbenska.htm.

14. Franko I. (1986). Mykhailo Petpovych Starytskyi : yoho zh Zibrannia tvopiv $v 50 t$. [Mykhailo Petpovych Starytskyi and his collection of works in 50 volumes]. Kyiv, 1986. 
B. A. Tымкова,

Винницкий торгово-экономический институт Киевского национального торгово-экономического университета, кафедра иностранной филологии и перевода

\section{ПСИХОАИНГВИСТИЧЕСКИЙ ПРОФИАЬ СОВРЕМЕННОГО СТУДЕНТА ЭКОНОМИЧЕСКИХ СПЕЦИААЬНОСТЕЙ}

В пределах статьи характеризируем отдельные аспекты проявления языковой, терминологической, коммуникативно-прагматической, текстовой, дискурсивной компетенций психолингвистического профиля специалиста экономической области. Определено влияние личностных характеристик экономиста как наставника на формирование языковой личности начинающего экономиста. Проанализировано научные работы, которые дают возможность определить языковую личность как личность, выраженную в языке и через язык; как личность, которая является носителем языка и коммуникантом, носителем языковой и коммуникативной компетенции.

Ключевые слова: языковая личность; экономеская область; лексические заимствования; языковая культура; профессиональные тексты; терминологическая компетенция.

\section{В. А. Тимкова,}

Вінницький торговельно-економічний інститут Київського начіонального торговельно-економічного університету, кафедра іноземної філології та перекладу

\section{ПСИХОАІНГВІСТИЧНИЙ ПРОФІАЬ СУЧАСНОГО СТУДЕНТА ЕКОНОМІЧНИХ СПЕЦІААЬНОСТЕЙ}

У межах статті характеризуємо окремі аспекти вияву мовної, термінологічної, комунікативно-прагматичної, текстової, дискурсивної компетенцій психолінгвістичного профілю фахівця економічної сфери. Визначено вплив особистісних рис економіста як наставника на формування мовної особистості економіста-початківця. Проаналізовано наукові праці, які дають змогу визначити мовну особистість як особистість, виражену в мові і через мову; як особистість, що $\epsilon$ носієм мови й комунікантом, носієм мовної і комунікативної компетенції. Зазначено три рівні володіння мовою: вербально-семантичний, лінгвокогнітивний, прагматичний, межі між якими досить нетривкі, розпливчасті, які водночас визначають етапи формування мовної особистості. Визначено вимоги до економічної компетенції фахівця, що забезпечують відповідний рівень володіння мовою, адже пріоритетне місце в професійному мовленні фахівців економічної галузі посідають лексичні одиниці мовної системи: економічна термінологія вузького й широкого вжитку, професіоналізми, соціально маркована лексика тощо. Проаналізовано внутрішньолінгвістичні причини динамічного проникнення лексичних запозичень у професійне мовлення сучасних економістів у зв'язку з номінативною необхідністю. При всій повазі до іншомовної культури все частіше й самі фахівці економічної сфери виступають за екологію професійного мовлення, прагнуть хоча б спорадично застосовувати й синонімічні українські відповідники до запозичень. Зазначено важливі комунікативні ознаки професійного мовлення: змістовність, точність, логічність, правильність, стислість викладу думок, доказовість, коректність та доречність уживання термінів, насиченість інформацією, чистота мови, виразність дикції, милозвучність. 
Таким чином, показниками загальнокультурної, мовної, термінологічної компетенції економіста є глибокі знання особливостей економічної термінології, теорії і практики мовленнєвого впливу, уважне ставлення до питомої лексики й фахових термінів. Сформованість психолінгвістичного профілю особистості економіста-початківця залежить від фундаментальної,мовної підготовки, прикладу і впливу особистісних рис економіста-наставника. Мовний розвиток сучасного економіста значною мірою залежить від державної підтримки, однак насамперед від власного прагнення до саморозвитку й самореалізації.

Ключові слова: мовна особистість; економічна галузь; лексичні запозичення; мовна культура; професійні тексти; термінологічна компетенція. 